\title{
Polymorphism of Placental Phosphoglucomutase in Japanese
}

\author{
Masakazu Oya, Reiko Shibata, Akira Kido and Nori \\ Komatsu \\ Department of Legal Medicine, Yamanashi Medical \\ University, Tamaho-mura 409-38
}

\begin{abstract}
Oya, M., Shibata, R., Kido, A. and Komatsu, N. Polymorphism of Placental Phosphoglucomutase in Japanese. Tohoku J. exp. Med., 1985, 146 (2), 189-192-Polymorphism of $\mathrm{PGM}_{1}$ and $\mathrm{PGM}_{3}$ types was investigated in placental extracts from 127 unrelated Japanese parturients living in Yamanashi Prefecture. The gene frequencies were 0.787 for $\mathrm{PGM}_{1}^{1}, 0.213$ for $\mathrm{PGM}_{1}^{2} ; 0.760$ for $\mathrm{PGM}_{3}^{1}, 0.240$ for $\mathrm{PGM}_{3}^{2}$, respectively. There was no significant association between the $\mathrm{PGM}_{1}$ and $\mathrm{PGM}_{3}$ systems. The $\mathrm{PGM}_{3}^{2}$ frequency in the present sample population was higher than those in Kanto District, but lower than those in Kinki District. —_ polymorphism ; population study; placental phosphoglucomutase type ; Japanese
\end{abstract}

Starch gel electrophoretic studies have shown that human red cell phosphoglucomutase (PGM) is separated into multiple isoenzyme components which are genetically controlled (Spencer et al. 1964). There have been three different autosomal loci found, $\mathrm{PGM}_{1}, \mathrm{PGM}_{2}$ and $\mathrm{PGM}_{3}$, each determining a separate group of PGM isoenzymes (Hopkinson and Harris 1965, 1968).

Although the polymorphism of $\mathrm{PGM}_{1}$ has been extensively investigated in the Japanese population, there have been only a few reports on that of $\mathrm{PGM}_{3}$ (Ishimoto 1969; Mabuchi 1971; Ishizaki 1975; Yoshida et al. 1978; Akiyama and Abe 1983). Since the $\mathrm{PGM}_{3}$ isoenzymes cannot ordinarily be detected in red cells, most of the work has been carried out using the placenta as the source of the enzyme. Data on the distribution of placental PGM types in a Japanese population of Yamanashi prefecture are presented in this report.

\section{Materials and Methods}

Human term placentae from single birth of 127 unrelated Japanese parturients were provided by the Department of Obstetrics and Gynecology, Yamanashi Prefectural Central Hospital and stored at $-20^{\circ} \mathrm{C}$ until use. A small piece of placental tissue was minced and homogenized in an equal volume of distilled water using an Ultra-Turrax homogenizer (Janke \& Kunkel AG, Staufen im Breisgau, FRG). The homogenates were centrifuged at $3,000 \mathrm{rpm}$ for $15 \mathrm{~min}$ and the supernatants were used for electrophoresis.

PGM typing was performed essentially as described by Hopkinson and Harris (1968).

Received November 5, 1984; accepted for publication, Februay 18, 1985. 
Starch gel electrophoresis was conducted at $4^{\circ} \mathrm{C}$ for $16 \mathrm{hr}$ with a voltage gradient of $5 \mathrm{~V} / \mathrm{cm}$. After electrophoresis the gels were stained in a thermostatic dark chamber at $37^{\circ} \mathrm{C}$ using an agarose overlay technique. $\mathrm{PGM}_{1}$ and $\mathrm{PGM}_{2}$ isoenzymes were demonstrated after $30 \mathrm{~min}$ incubation, while $\mathrm{PGM}_{3}$ isoenzymes were able to be detected after 120 min incubation.

\section{Results and Descussion}

Fig. 1 depicts the typical electrophoretic patterns of PGM types in human placentae; all the placentae were typed as $\mathrm{PGM}_{2}^{1}$. This is not surprising as the variation at the $\mathrm{PGM}_{2}$ locus is extremely rare among the Japanese (Nishigaki et al. 1982 ; Satoh et al. 1984).

The results for the distribution and gene frequencies of $\mathrm{PGM}_{1}$ and $\mathrm{PGM}_{3}$ types are shown in Table 1 . The samples studied included no rare variants. In both systems the observed numbers are in good agreement with the expected numbers on the basis of the Hardy-Weinberg law $\left(\chi^{2}=0.154\right.$, d.f. $=1,0.5<p<0.7$

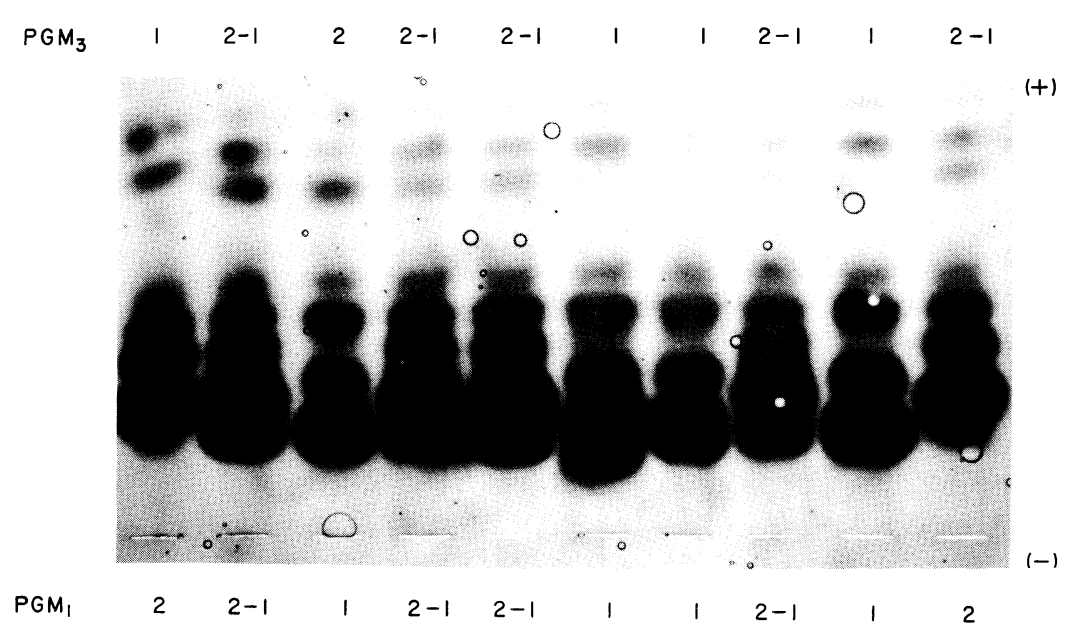

Fig. 1. Starch gel electrophoretic patterns of PGM types in human placentae. Cathodal components, $\mathrm{PGM}_{1}$; anodal components, $\mathrm{PGM}_{3}$; intermediate components, $\mathrm{PGM}_{2}$.

Table 1. Distribution of $P G M_{1}$ and $P G M_{3}$ types in Japanese placentae

\begin{tabular}{lrrrr}
\hline & $\mathrm{PGM}_{1} 1$ & $\mathrm{PGM}_{1} 2-1$ & $\mathrm{PGM}_{1} 2$ & \multicolumn{1}{c}{ Total } \\
\hline $\mathrm{PGM}_{3} 1$ & $45(45.45)$ & $30(28.74)$ & $3(4.55)$ & $78(78.74)$ \\
$\mathrm{PGM}_{3} 2-1$ & $25(24.55)$ & $17(15.52)$ & $2(2.45)$ & $44(42.52)$ \\
$\mathrm{PGM}_{3} 2$ & $1(3.31)$ & $4(2.10)$ & $0(0.33)$ & $5(5.74)$ \\
Total & $71(73.31)$ & $51(46.36)$ & $5(7.33)$ & $127(127.00)$ \\
\hline
\end{tabular}

Gene frequency $: \mathrm{PGM}_{1}^{1}=0.787, \mathrm{PGM}_{1}^{2}=0.213$

$\mathrm{PGM}_{3}^{1}=0.760, \mathrm{PGM}_{3}^{2}=0.240$ 
TABLE 2. $\quad P G M_{3}$ gene frequencies in various Japanese populations

\begin{tabular}{llccll}
\hline Population & Source & $\begin{array}{c}\text { No. } \\
\text { observed }\end{array}$ & $\mathrm{PGM}_{3}^{1}$ & $\mathrm{PGM}_{3}^{2}$ & Reference \\
\hline Mie & Placentae & 370 & 0.809 & 0.191 & Ishimoto 1969 \\
Osaka & Placentae & 625 & 0.806 & 0.194 & Mabuchi 1971 \\
Tokyo & Placentae & 108 & 0.708 & 0.292 & Ishizaki 1975 \\
Kanagawa & Hair roots & 248 & 0.621 & 0.379 & Yoshida et al. 1978 \\
Tokyo & Leucocytes & 76 & 0.711 & 0.289 & Akiyama and Abe 1983 \\
Yamanashi & Placentae & 127 & 0.760 & 0.240 & Present study \\
\hline
\end{tabular}

for $\mathrm{PGM}_{1} ; \chi^{2}=1.279$, d.f. $=1,0.2<p<0.3$ for $\left.\mathrm{PGM}_{3}\right)$. There is no significant association between the $\mathrm{PGM}_{1}$ and $\mathrm{PGM}_{3}$ systems $\left(\chi^{2}=4.481\right.$, d.f. $=4,0.3<p<$ $0.5)$.

In Table 2 are summarized the gene frequencies of $\mathrm{PGM}_{3}$ types so far reported for Japanese. The $\mathrm{PGM}_{3}^{2}$ frequency in the present sample $(0.240)$ is higher than those estimated in Mie (0.191) and in Osaka (0.194), but lower than those estimated in Tokyo (0.292), in Tokyo (0.289) and in Kanagawa (0.379). It may therefore be probable that the $\mathrm{PGM}_{3}^{2}$ frequency is high in Kanto District and low in Kinki District, and the $\mathrm{PGM}_{3}^{2}$ frequency in Yamanashi prefecture (Chubu District) lies between those in the above two districts. The population data accumulated up to now are so limited that at present it is premature to conclude that there exists a cline. Further population studies in various districts will solve this problem, particularly in the north-eastern and south-western parts of Japan.

\section{References}

1) Akiyama, K. \& Abe, K. (1983) Genetic polymorphism of leukocyte phosphoglucomutase locus-3 isozymes. J. Tokyo Women's med. College, 53, 489-493. (in Japanese with English abstract)

2) Hopkinson, D.A. \& Harris, H. (1965) Evidence for a second 'structural' locus determining human phosphoglucomutase. Nature (Lond.), 208, 410-412.

3) Hopkinson, D.A. \& Harris, H. (1968) A third phosphoglucomutase locus in man. Ann. hum. Genet., 31, 359-367.

4) Ishimoto, G. (1969) Placental phosphoglucomutase in Japanese. Jap. J. hum. Genet., 14, 183-188.

5) Ishizaki, K. (1975) Enzyme polymorphism in placenta and cord blood of new born babies in Japan. $J$. anthrop. Soc. Nippon, 83, 39-48.

6) Mabuchi, Y. (1971) Studies on placental polymorphic systems in Japanese. Bull. Osaka med. Sch., 17, 51-59.

7) Nishigaki, I., Itoh, T. \& Hasegawa, I. (1982) A rare phenotype of phosphoglucomutase-2 first detected in Mongoloids. Hum. Genet., 62, 246-249.

8) Satoh, C., Takahashi, N., Asakawa, J., Masunari, N., Fujita, M., Goriki, K., Hazama, R. \& Iwamoto, K. (1984) Electrophoretic variants of blood proteins in Japanese : I. phosphoglucomutase-2 $\left(\mathrm{PGM}_{2}\right)$. Jap. J. hum. Genet., 29, 89-104.

9) Spencer, N., Hopkinson, D.A. \& Harris, H., (1964) Phosphoglucomutase polymorphism in man. Nature (Lond.), 204, 742-745.

10) Yoshida, H., Abe, T. \& Nakamura, F. (1978) Studies on the frequencies of $\mathrm{PGM}_{1}$, 
$\mathrm{PGM}_{3}$ and Es-D types from hair roots in Japanese subjects and the determination of these types from old hair roots. Forensic Sci., 14, 1-7. 